\title{
PENYULUHAN HUKUM TENTANG PROSEDUR PENANGANAN PERKARA PIDANA DI DESA SANGIANG, MAJALENGKA
}

\author{
Suwari Akhmaddhian \\ Fakultas Hukum, Universitas Kuningan, Kuningan, Indonesia \\ Email: suwari_akhmad@uniku.ac.id
}

\begin{abstract}
Every citizen has the right in law and justice, because of that the government made Law number 16 of 2011 concerning Legal Aid to protect its citizens in the event of a disaster that befalls the community. The purpose of community service is more focused on the people or villagers, while the other objectives of this counseling are the parents who can add information related to the process of handling criminal acts and how to follow up in the event of a crime. The method used is by way of lectures and discussions then ends with questions and answers. The results obtained from this community service are that the community is more sensitive and knows how criminal law and the process of resolving criminal acts, starting from the investigation and investigation, prosecution and court decision. defendant.
\end{abstract}

Keywords: Legal Aid, Prevention, Socialization.

\begin{abstract}
Abstrak
Setiap warga negara mempunyai hak dalam hukum dan keadilan, oleh kerana itu pemerintah membuat Undang-Undang nomor 16 Tahun 2011 tentang Bantuan Hukum untuk melindungi warganya dalam hal terjadi musibah yang menimpa masyarakat. Tujuan pengabdian kepada masyarakat ini lebih menitik beratkan kepada orang-orang atau warga desa, adapun sasaran lain yang menjadi tujuan dari diadakannnya penyuluhan ini yaitu para orang tua yang mana dapat menambah informasi terkait dengan proses penanganan tindak pidana dan bagaimana menindaklanjuti apabila terjadi tindak pidana. Metode yang digunakan yaitu dengan cara ceramah dan diskusi kemudian diakhiri dengan tanya jawab. Hasil yang diperoleh dari pengabdian kepada masyarakat ini yaitu masyarakat lebih peka dan mengetahui bagaimana hokum pidana dan proses penyelesaian tindak pidana yaitu mulai dari penyelidaikan dan penyidikan, penuntutan dan putusan pengadilan.masyarakat mengetahui tentang tahapan-tahapan dalam proses penyelesian perkara pidana yang dilalui seorang tersangka atau terdakwa.
\end{abstract}

Kata Kunci: Bantuan Hukum, Pencegahan, Sosialisasi.

\section{PENDAHULUAN}

Pasca reformasi tahun 1998 di Indonesia, salah satu agenda dalam mensejahterakan masyarakat terutama dibidang penegakan hukum sampai sekarang masih dipertanyakan. Orientasi penegakan hukum di Indonesia sendiri dititikberatkan pada pengadilan, kepolisian, kejaksaan, serta lembaga bantuan hukum baik itu pengacara ataupun lembaga bantuan hukum masyarakat, masih belum berjalan maksimal. Penegakan negara yang bersupermasi hukum menemui jalan buntu. Penegakan hukum di satu sisi dan keadilan dimasyarakat di sisi lain diperlukan keselarasan, terutama dalam hak mendapatakan bantuan hukum bagi masyarakat dengan tidak membedabedakan ras, agama, dan golongan. Sebagaimana amanah UUD 1945 terutama Pasal 27 baik yang telah diamandemen ataupun sebelum amandemen. Penjabaran UUD 1945 Pasal 27 dieterjemahkan ke dalam UU No. 16 Tahun 2011 Tentang bantuan hukum. Hukum dalam bentuknya ada dua yakni: Pertama,bersifat tidak tertulis dimana hukum yang demikian merupakan aturan hukum yang hidup dalam masyarakat atau yang sering dikatakan sebagai hukum adat; Kedua,hukum tertulis yakni dibuat oleh lembaga yang berwenang dan memiliki sanksi serta bersifat memaksa. Perbedaan keduannya terletak pada bentuk dan sanksinya. Bentuk hukum tidak tertulis hanya merupaka peraturan yang diturunkan secara turun temurun dan kurang memiliki 
sanksi yang tegas, sementara hukum tertulis selain memiliki sanksi yang tegas juga memiliki kejelasan tentang lembaga yang membuatnya. ${ }^{1}$ Sejalan dengan pendapat Soerjono Soekanto tentang penegakan hukum yang dipengaruhi oleh 5 (lima) faktor yaitu²: Pertama: Faktor hukum dan peraturan per Undang undangan, Kedua: Faktor aparat penegak hukumnya yakni pihak pihak pihak yang terlibat dalam proses pembuatan hukumnya dan pemberlakuanya, Ketiga;Faktor sarana dan prasarana,yang mendukung proses penegakan hokum,Keempat;Faktor kesadaran masyarakat, yakni lingkungan sosial dimana hukum tersebut berlaku atau diberlakukan, Kelima; Faktor Kebudayaan yakni hasil karya, cipta dan rasa yang didasarkan pada karsa manusia didalam pergaulan hidup ${ }^{3}$. Masyarakat Kabupaten kuningan pasca reformasi merindukan program bantuan hukum gratis, harus menjadi solusi alternatif bagi masyarakat tidak mampu dalam rangka penegakan hukum agar keadilan masyarakat kuningan dalam mencapai nilai-nilai keadilan dan sekaligus menciptakan Kabupaten Kuningan ASRI. Kebutuhan bantuan hukum tersebut dapat dikatakan sebagai bentuk untuk mencegah masyarakat menjadi korban kejahatan dan menyelesaikan kasus kasus kejahatan yang terjadi sehingga masyarakat puas bahwa keadilan telah ditegakan dan yang bersalah telah di pidana. Mengusahakan agar mereka yang telah melakukan kejahatan tidak mengulangi lagi kejahatanya ${ }^{4}$ ). Semuanya diperlukan untuk mengubah paradigma bahwa hukum itu penuh dengan sanksi yang kejam dalam masyarakat di Kabupaten Kuningan. Prinsipnya bantuan hukum terbagi menjadi dua, yaitu : Litigasi dan Non litigasi diperlukan pendampingan melalui program pemerintah darah Kabupaten Kuningan.

Penegkan hukum dilakukan secara preventive dan represif. rangka untuk menanggulangi tindak pidana kehutanan. Kegiatan dengan pemberantasan perusakan hutan yang dilakukan dengan cara menindak secara hukum atau penegakan hukumterhadap pelaku perusakan hutan.Penegakan hukum dalam penang-gulangan tindak pidana kehutanan,dalam hal melakukan 3 (tiga) unsur yangselalu harus diperhatikan yaitu; Kepastian Hukum Keadilan dan Kemanfaatanterhadap Perbuatan perusakan hutan atautindak pidana yang dilakukan terhadaphutan, kawasan hutan dan peredaran hasil hutan baik langsung, tidak langsung,maupun yang terkait lainnya ${ }^{5}$.

\section{METODE PELAKSANAAN}

Melaksanakan Pengabdian Kepada Masyarakat ini selaku pemateri saya memberikan pemaparan dalam bentuk power point agar masyarakat dapat

\footnotetext{
${ }^{1}$ Suwari Akhmaddhian dan Erga Yuhandra. 2018. "Bantuan Hukum Bagi Tenaga Pendidik Dan Kependidikan Di Desa Mancagar Kabupaten Kuningan, Indonesia". Empowerment : Jurnal Pengabdian Masyarakat, e-ISSN 2598-2052 Vol. 01 Nomor 01. 2018.72-78.

2 Suwari Akhmaddhian. Penegakan Hukum Lingkungan dan Pengaruhnya Terhadap Pertumbuhan Ekonomi di Indonesia (Studi Kebakaran Hutan Tahun 2015). Jurnal Unifikasi, ISSN 2354-5976 Vol. 03 Nomor 01 Januari 2016.

${ }^{3}$ Soerjono Soekanto, Bantuan Hukum Suatu tinjauan Sosio-Yuridis, Ghalia Indah,Jakarta, 1983, hlm.15.

${ }^{4}$ Romli Atmasasmita, Sistem Peradilan Pidan Kontemporer , Jakarta: Kencana, 2011, hlm 3.

${ }^{5}$ Astan Wirya, Kebijakan Formulasi Hukum Pidana Dalam Penanggulangan Tindak Pidana Kehutanan Jurnal IUS Kajian Hukum Dan Keadilan. Vol III . Nomor 7. April 2015 Hlm19-41.
} 
memperhatikan dengan lebih cermat, serta menambahkan berbagai gambar-gambar sebagai contoh dari tema yang akan dibahas sehingga mereka lebih memahami akan realita yang sebenarnya. Metode yang digunakan dalam Pengabdian Kepada Masyarakat ini melalui metode ceramah dan diskusi dan tanya jawab, dengan tanya jawab ini masyarakat diberikan kesempatan untuk bertanya sesuai dengan tema penyuluhan, atau masyarakat dapat bertanya di luar tema yang telah ditentukan.

Sasaran kegiatan pengabdian masyarakat ini dilakukan dengan harapan perubahan prilaku sosial yang ada di masyarakat dengan melakukan penyuluhan dengan sasaran yang menjadi tujuan pengabdian ini lebih menitik beratkan kepada yaitu para orang tua yang mana memiliki anak yang harus dijaga dan dilindungi. Lokasi Pengabdian Kepada Masyarakat ini dilakukan tepatnya di Desa Sangiang Kabupaten Majalengka pada Bulan Agustus 2017.

\section{HASIL DAN PEMBAHASAN}

Jenis-jenis pidana dalam proses penegakan hokum terhadap suatu tindak pidana atau kejahatan, suatu perbuatan pidana tidakbisa terlepas dari sanksi pidana dan sistem pemidanaan terhadap terjadinyasuatu perbutan pidana. Jenis-jenis pidana berdasarkan ketentuan Kitab Undang Undang Hukum Pidana (KUHP) terdapat ada 2 (dua) jenis yaitu pidanapokok dan pidana tambahan, sebagaimana ditentukan dalam BAB II Pasal 10 KUHPdinyatakan tentang jenis pidana sebagai berikut terdiri $\operatorname{atas}^{6}$ :

1. Pidana Pokok :

a. Pidana Mati;

b. Pidana Penjara;

c. Kurungan;

d. Denda;

2. Pidana Tambahan

a. Pencabutan hak-hak tertentu;

b. Perampasan barang-barang tertentu;

c. Pengumuman putusan hakim.

Pengertian penyelidikan adalah serangkaian tindakan penyidik untuk mencari dan menemukan suatu peristiwa yang diduga sebagai tindak pidana guna menentukan dapat atau tidaknya dilakukan penyidikan menurut cara yang di atur dalam Undang-undang.1 Penyelidikan adalah serangkaian tindakan penyelidik untuk mencari dan menemukan suatu peristiwa yang diduga sebagai tindak pidana guna menentukan dapat atau tidaknya dilakukan penyidikan menurut yang diatur dalam Undangundang ini. ${ }^{7} 2$ Fungsi penyidik dilakukan sebelum dilakukan penyelidikan hanya bertugas untuk mengetahui dan menentukan peristiwa apa yang sesungguhnya telah terjadi dan bertugas mambuat berita acara serta laporannya nantinya merupakan dasar permulaan penyidikan.

Penyelidikan dilakukan berdasarkan : a. Informasi atau laporan yang diterima maupun diketahui langsung oleh penyelidik/penyidik b. Laporan polisi c. Berita Acara

\footnotetext{
${ }^{6}$ Astan Wirya, Ibid.

${ }^{7}$ M. Husein Harun. Penyidik dan Penuntut dalam Proses Pidana. PT Rineka Cipta. Jakarta. 1991.
} 
pemeriksaan di TKP d. Berita Acara pemeriksaan tersangka dan atau saksi3 Proses penyidikan tindak pidana penyelidikan dilakukan untuk : a. Mencari keteranganketerangan dan bukti guna menentukan suatu peristiwa yang di laporkan atau diadukan, apakah merupakan tindak pidana atau bukan. b. Melengkapi keterangan dan bukti-bukti yang telah di proses agar menjadi jelas sebelum dilakukan penindakan selanjutnya c. Persiapan pelaksanaan penindakan dan atau pemeriksaan. Penyelidikan bukanlah fungsi yang berdiri sendiri melainkan hanya merupakan salah satu metode atau sub dari fungsi penyidikan.4 Pengertian penyidikan Istilah penyidikan dipakai sebagai istilah hukum pada Tahun 1961, yaitu sejak dimuatnya dalam Undang-Undang pokok kepolisian No. 13 Tahun 1961. Sebelumnya dipakai istilah pengusutan yang merupakan terjemah dari bahasa Belanda, yaitu opsporin.

Pasal 1 butir 2 (Kitab Undang-undang Hukum Acara Pidana) KUHAP diuraikan bahwa : "penyidikan adalah serangkaian tindakan penyidik dalam hal dan menurut cara yang diatur dalam undang-undang, mencari dan mengumpulkan bukti yang dengan bukti itu membuat terang tentang tindak pidana yang terjadi dan guna menemukan tersangkanya" Berbicara mengenai penyidikan tidak lain dari membicarakan masalah pengusutan kejahatan atau pelanggaran, orang Inggris lazim menyebutnya dengan istilah "criminal investigation" Tujuan penyidikan adalah untuk menunjuk siapa yang telah melakukan kejahatan dan memberikan pembuktian-pembuktian mengenai masalah yang telah dilakukannya. Untuk mencapai maksud tersebut maka penyidik akan menghimpun keterangan dengan fakta atau peristiwa-peristiwa tertentu5 . Penyidikan yang diatur dalam undang-undang, ini dapat dilaksanakan setelah diketahui bahwa suatu peristiwa telah terjadi tindak pidana dimana dalam Pasal 1 butir 2 KUHAP berbunyi bahwa penyidikan adalah serangkaian tindakan penyidik mengumpulkan bukti yang dengan bukti itu membuat terang tindak pidana yang terjadi guna menemukan tersangkanya. Penyidikan dimulai sesudah terjadinya tindak pidana untuk mendapatkan keterangan-keterangan tentang : a. Tindak pidana apa yang telah dilakukan b. Kapan tindak pidana itu dilakukan c. Dimana tindak pidana itu dilakukan d. Dengan apa tindak pidana itu dilakukan e. Bagaimana tindak pidana itu dilakukan f. Mengapa tindak pidana itu dilakukan g. Siapa pembuatnya

Proses penyidikan tindak pidana, bahwa penyidikan meliputi : a. Penyelidikan b. Penindakan 1). Pemanggilan 2). Penangkapan 3). Penahanan 4). Penggeledahan 5). Penyitaan c. Pemeriksaan 1). Saksi 2). Ahli 3). tersangka d. Penyelesaian dan penyerahan berkas perkara 1). Pembuatan resume 2) penyusuna berkas perkara 3) penyerahan berkas perkara6

Pengertian penuntutan dalam KUHAP dijelaskan dalam Pasal 1 angka 7 yang berbunyi sebagai berikut: "Penuntutan adalah tindakan penuntut umum untuk melimpahkan perkara pidana ke Pengadilan Negeri yang berwenang dalam hal dan menurut cara yang diatur dalam undang-undang ini dengan permintaan supaya diperiksa dan diputus oleh hakim di sidang pengadilan". Menuntut seorang terdakwa di muka hakim pidana adalah menyerahkan perkara seorang terdakwa dengan berkas perkaranya kepada hakim, dengan permohonan supaya hakim memeriksa dan kemudian 
memutuskan perkara pidana itu terhadap terdakwa. Tujuan penuntutan adalah untuk mendapat penetapan dari penuntut umum tentang adanya alasan cukup untuk menuntut seorang terdakwa di muka hakim ${ }^{8}$. KUHAP tidak menjelaskan kapan suatu penuntutan itu dianggap telah ada, dalam hal ini Moeljatno menjelaskan bahwa, yang dapat dipandang dalam konkretnya sebagai tindakan penuntutan adalah: a. apabila jaksa telah mengirimkan daftar perkara kepada hakim disertai surat tuntutannya. b. apabila terdakwa ditahan dan mengenai tempo penahanan dimintakan perpanjangan kepada hakim sebab apabila sudah lima puluh hari waktu tahanan masih dimintakan perpanjangan secara moril boleh dianggap bahwa jaksa sudah menganggap cukup alasan untuk menuntut. c. apabila dengan salah satu jalan jaksa memberitahukan kepada hakim bahwa ada perkara yang akan diajukan kepadanya ${ }^{9}$.

Penuntutan suatu perkara dapat dilakukan dengan berbagai cara. Cara tersebut bergantung pada berat ringannya suatu perkara. Jika perkara itu termasuk perkara biasa yang ancaman pidananya di atas satu tahun maka penuntutannya dilakukan dengan cara biasa, hal ini ditandai dengan adanya berkas perkara yang lengkap dan rumit. Ciri utama dalam penuntutan ini adalah selalu disertai dengan surat dakwaan yang disusun secara cermat dan lengkap oleh penuntut umum. Selain penuntutan dengan cara biasa tersebut, penuntutan dapat pula dilakukan dengan cara singkat. Penuntutan ini dilakukan jika perkaranya diancam pidana lebih ringan, yakni tidak lebih dari satu tahun penjara. Berkas perkara biasanya tidak rumit, dan penuntut umum tetap mengajukan surat dakwaan yang disusun secara sederhana.

Jenis penuntutan lainnya adalah penuntutan dengan cara cepat. Penuntutan jenis ini terjadi pada perkara yang ringan atau perkara lalu lintas yang ancaman hukumannya tidak lebih dari tiga bulan. Penuntutan tidak dilakukan oleh penuntut umum, namun diwakili oleh penyidik dari polisi. Dalam hal ini juga tidak ada surat dakwaan tetapi hanya berupa catatan kejahatan atau pelanggaran yang dilakukan. Selanjutnya Pasal 141 KUHAP menentukan bahwa penuntutan dapat dilakukan dengan menggabungkan perkara dengan satu surat dakwaan. Tetapi kemungkinan penggabungan itu dibatasi dengan syarat-syarat oleh pasal tersebut. Syarat-syarat itu adalah: a. Beberapa tindak pidana yang dilakukan oleh seorang yang sama dan kepentingan pemeriksaan tidak menjadikan halangan terhadap penggabungannya; b. Beberapa tindak pidana yang bersangkut-paut satu dengan yang lain; c. Beberapa tindak pidana yang tidak bersangkut-paut satu dengan yang lain, akan tetapi satu dengan yang lain itu ada hubungannya, yang dalam hal ini penggabungan tersebut perlu bagi kepentingan pemeriksaan.

Secara umum biasanya penuntutan dihentikan atau dicabut sebagaimana yang diatur dalam Buku I Bab VIII KUHP, yaitu: a. Telah ada putusan hakim yang tetap (de kracht van een rechterlijk gewijsde) mengenai tindakan (feit) yang sama (Pasal 76) b. Terdakwa meninggal (Pasal 77) c. Perkara telah kadaluarsa (Pasal 78) d. Terjadi penyelesaian di luar pengadilan (Pasal 82). Pengadilan merupakan tempat

\footnotetext{
${ }^{8}$ Muhammad, H. Rusli, 2007, Hukum Acara Pidana Kontemporer, Citra Aditya Bakti, Bandung.

${ }^{9}$ Muhammad, H. Rusli, Ibid.
} 
berlangsungnya proses peradilan, kewenangan untuk mengadakan pengadilan terdapat pada lembaga kehakiman. Diatur dalam UU No. 48 Tahun 2009 tentang Kekuasaan Kehakiman. Berdasarkan Pasal 10 UU Kekuasaan Kehakiman, pengadilan berwenang untuk memeriksa, mengadili, dan memutus suatu perkara yang diajukan ke muka pengadilan. Dalam proses persidangan, hakim memimpin secara aktif sesuai stelsel aktif hakim dalam hukum acara pidana. Keaktifan ini meliputi memimpin persidangan dan mengatur pertanyaan-pertanyaan pada saksi, ahli, dan terdakwa, dan memutuskan semua substansi perkara, termasuk dalam menyeleksi alat bukti yang boleh diajukan untuk didengarkan dalam sidang sekalipun para pihak telah memintanya. Setelah memeriksa semua alat bukti, jaksa penuntut umum mengajukan surat tuntutan (requisitoir) yang dapat ditanggapi terdakwa dengan pembelaan (pledoi).

Setelah berlangsung proses pembuktian dalam persidangan maka masuklah ke dalam tahapan putusan. Berdasarkan Pasal 1 angka 11 KUHAP, putusan pengadilan adalah pernyataan hakim yang diucapkan dalam sidang pengadilan terbuka, yang dapat berupa pemidanaan atau bebas atau lepas dari segala tuntutan hukum dalam hal serta menurut cara yang diatur dalam undang-undang ini.

Putusan pengadilan hanya sah dan mempunyai kekuatan hukum apabila diucapkan dalam sidang terbuka untuk umum. Dalam menjatuhkan putusan, hakim memiliki wewenang yang besar dalam memutus perkara karena hakim di Indonesia menganut aliran pembuktian berdasarkan keyakinan hakim yang timbul dari alat bukti menurut Pasal 184 KUHAP secara negatif (negatief wettelijk bewijstheorie). Artinya, dalam pembuktian, selain mengacu kepada Pasal 184 KUHAP, hakim juga menggunakan keyakinannya dan sekalipun menggunakan keyakinannya, keyakinan hakim tersebut terbatas pada alat bukti sesuai Pasal $184 \mathrm{KUHAP}^{10}$.

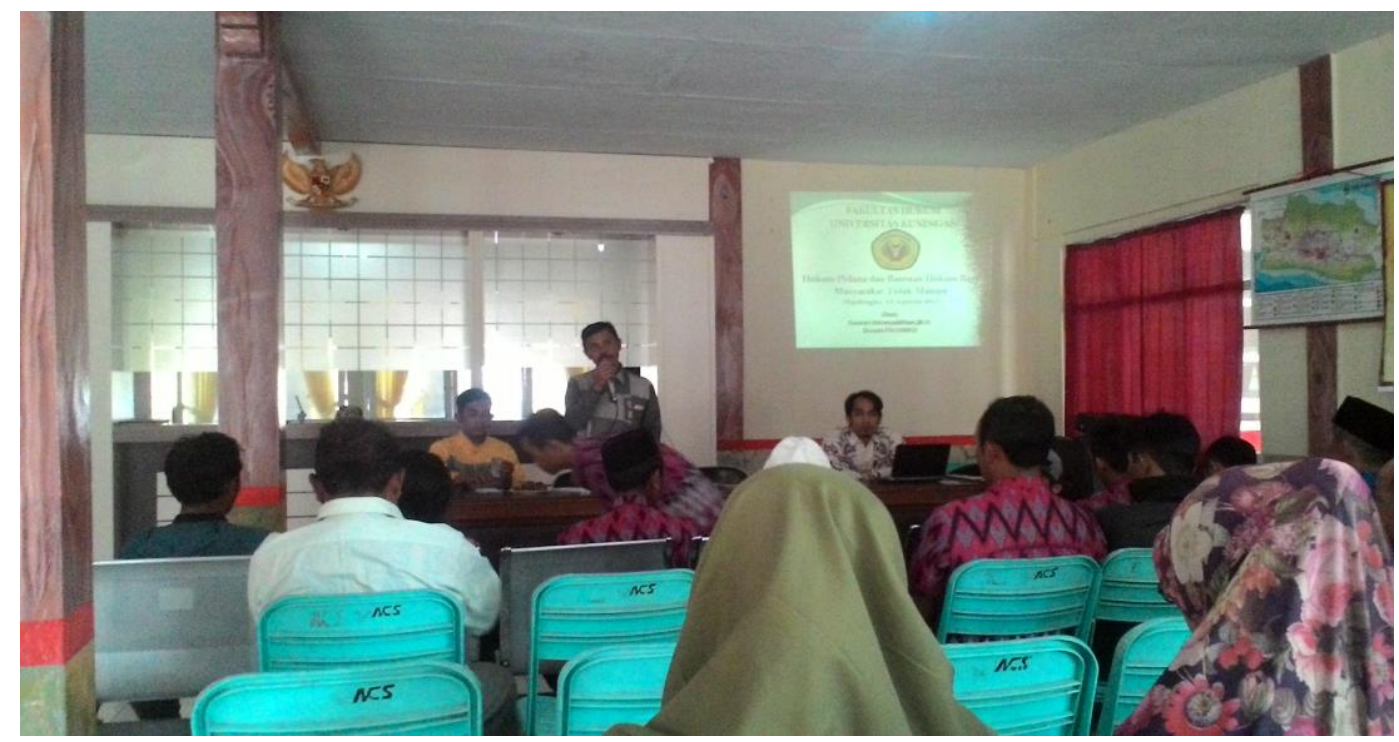

Gambar. Penyuluhan hukum di Desa Sangiang

\footnotetext{
${ }^{10}$ Muhammad, Rusli. (2008). Hukum Acara Pidana Kontemporer. Bandung: Alumni.
} 


\section{SIMPULAN}

Hasil yang diperoleh dari pengabdian kepada masyarakat ini yaitu masyarakat lebih peka terhadap permasalahan hukum khususnya yang berkaitan dengan hukum pidana seperti jaman sekarang ini, diharapkan dengan adanya pengabdian kepada masyarakat ini mengetahui dan memahami dengan baik terkait dengan hokum pidana yang berlaku di Indonesia. Dengan kegiatan ini pemahaman tentang hukum masyarakat menjadi meningkat dan sangat antusias dengan kegiatan pengabdian tersebut. Tentang kegiatan ini saya merekomendasikan agar kegiatan pengabdian kepada masyarakat perlu ada upaya antara Uniku berkerja sama dengan pemerintahan desa supaya kegiatan pengabdian ini optimal dan dapat dilakukan secara berjangka, sehingga peran serta masyarakat lebih antusias.

\section{SARAN}

Peningkatan pengetahuan masyarakat terkait pengetahuan hukum khususnya hukum pidana perlu terus ditingkatkan dan melibatkan semua unsur masyarakat sehingga masyarakat luas semakin tahu dan dapat menjalankan kehidupan berbangsa dan bernegara secara baik dan benar.

\section{UCAPAN TERIMA KASIH}

Penulis ucapkan terima kasih kepada Ketua Pusat Konsultasi dan Bantuan Hukum FH UNIKU, Dekan Fakultas Hukum Universitas Kuningan, Rektor Universitas Kuningan, Pemerintah Daerah Kabupaten Kuningan serta Badan Pembinaan Hukum Nasional (BPHN) Kementerian Hukum dan HAM RI atas segala dukungan yang telah diberikan sehingga terselenggaranya kegiatan pengabdian ini serta berbagi pihak yang telah membantu pelaksanaan kegiatan pengabdian ini.

\section{DAFTAR PUSTAKA}

Astan Wirya. 2016. Kebijakan Formulasi Hukum Pidana Dalam Penanggulangan Tindak Pidana Kehutanan Jurnal IUS Kajian Hukum dan Keadilan. Vol III . Nomor 7. April 2015 Hlm19-41.

M. Husein Harun. 1991. Penyidik dan Penuntut dalam Proses Pidana. PT. Rineka Cipta. Jakarta.

Muhammad, H. Rusli. 200., Hukum Acara Pidana Kontemporer, Citra Aditya Bakti, Bandung.

Muhammad, Rusli. 2008. Hukum Acara Pidana Kontemporer. Bandung: Alumni.

Soerjono Soekanto. 1983. Bantuan Hukum Suatu tinjauan Sosio-Yuridis, Ghalia Indah,Jakarta, 1983.

Suwari Akhmaddhian dan Erga Yuhandra. 2018. "Bantuan Hukum Bagi Tenaga Pendidik Dan Kependidikan Di Desa Mancagar Kabupaten Kuningan, Indonesia". Empowerment : Jurnal Pengabdian Masyarakat, e-ISSN 25982052 Vol. 01 Nomor 01. 2018.72-78. 
Empowerment : Jurnal Pengabdian Masyarakat, e-ISSN 2598-2052

Vol. 02 Nomor 02. 2019. 101-108.

Suwari Akhmaddhian. 2015. Penegakan Hukum Lingkungan dan Pengaruhnya Terhadap Pertumbuhan Ekonomi di Indonesia (Studi Kebakaran Hutan Tahun 2015). Jurnal Unifikasi, ISSN 2354-5976 Vol. 03 Nomor 01 Januari 2016.

Romli Atmasasmita. 2011. Sistem Peradilan Pidan Kontemporer, Jakarta: Kencana 